\title{
The Fern Genus Arachniodes (Dryopteridaceae): A New Record for the Flora of Vietnam
}

\author{
Vu Phuong Linh ${ }^{1}$, Nguyen Trung Thanh, ${ }^{1, *}$, Doan Hoang Son ${ }^{2}$, Lu Thi Ngan ${ }^{3}$ \\ ${ }^{I}$ VNU University of Science, 334 Nguyen Trai, Hanoi, Vietnam \\ ${ }^{2}$ Institute of Ecology and Biological Resources, Vietnam Academy of Science and Technology, \\ 18 Hoang Quoc Viet, Cau Giay, Hanoi, Vietnam. \\ ${ }^{3}$ Vietnam National Museum of Nature, Vietnam Academy of Science and Technology, \\ 18 Hoang Quoc Viet, Cau Giay, Hanoi, Vietnam
}

Received 02 August 2020

Revised 22 November 2020; Accepted 29 November 2020

\begin{abstract}
This paper presents a new record of the fern genus Arachniodes Blume from Vietnam, Arachniodes simplicior. The paper provides a detailed description of the new species based on the traditional morphological method, of which micro morphological characters of spores were firstly described based on the specimens collected from Quang Binh (Minh Hoa district), Vietnam. In addition, type materials of $A$. simplicior were analyzed and a specimen from MAK (MAK012702) was designated as a lectotype.
\end{abstract}

Keywords: Arachniodes simplicior, Dryopteridaceae, new record, flora of Vietnam.

\section{Introduction}

The genus Arachniodes Blume (Dryopteridaceae) is one of the most confusing and controversial fern genera in terms of circumscription, nomenclature, and taxonomy. It is a pantropical genus commonly distributed in subtropical and tropical forest regions of the world, mainly (abundant) in China and southern and southeastern Asia [1] with 60 species (PPGI - 2016) [2]; in Kew Science (Plants of the world

\footnotetext{
* Corresponding author.

Email address: thanhntsh@gmail.com

https://doi.org/10.25073/2588-1140/vnunst.5106
}

online) [3] listed 67 accepted species and 14 hybrids while the most recently study by Lu et al. in 2018 showed that the genus contains about 83 species worldwide [4]. China is considered as one of the most diversity centers of Arachniodes with 40 species are recorded [5]. In Vietnam, the number species of the genus has more than double since Pham and Phan studied of two decades ago $[7,8]$. There are 11 species have listed by Phan in 2010 [6] and not include 
Arachniodes simplicior. Three new species of Arachniodes were added for the flora of Vietnam by Lu et al., 2018 [9], those new findings have increased the number species of the genus Arachniodes for Vietnam to $14 \mathrm{spp}$. In early 2020, while revising a taxonomy of this genus in Vietnam, Arachniodes simplicior has been recognized from the specimens collected in Quang Binh prov. (Minh Hoa distr.) of Vietnam. Previously, its distribution has been known only in China North-Central, China South-Central, China Southeast, Japan and Korea [3]. In this paper, A. simplicior is described as a new species record for the flora of Vietnam. The general morphological and spore characteristics, a lectotypification of A. simplicior are also will be presented in this study.

\section{Materials and Methods}

Material: Morphological study is based on specimens collected in the field and stored at Vietnam National Museum of Nature (VNMN). Online specimens and syntypes of species were also examined.

Method: We have applied the literature reviews plus morphological comparison method association with scanning electron microscopy (SEM) to observe microstructural features (spore morphology) in this study. The SEM equipment, namely Hitachi TM0101 located in VNMN.

\section{Result and Discussion}

\section{Taxonomic treatment:}

Arachniodes simplicior (Makino) Ohwi, Journal of Japanese Botany (J. Jap. Bot.) 37 (3): 76. 1962. Basionym: Aspidium aristatum var. simplicior Makino, Botanical Magazine (Bot. Mag.), Tokyo 15(170): 65-66. 1901. (Fig.1)

Type: -JAPAN. Tosa Province (Kōchi Prefecture): Takaoka-gori, 1884, $T$. Makino s.n. (lectotype, designated here: MAK: MAK012702! (Fig. 2), isolectotypes: TI:
TI00010763!, MAK: MAK012700!, MAK012701!, MAK012703!).

Description (mainly based on Zhang and Lu 7461):

Plants 58-107 cm tall. Rhizomes short creeping and covered with densely scales; scales on rhizomes dark-brown, linear-lanceolate, 0.5$0.8 \mathrm{~cm}$ long, membranous, entire, gradually narrowed and short tortuous at the apex. Stipe $28-55 \mathrm{~cm} \times 2-4 \mathrm{~mm}$, straw to dark brown at base, scattered scales along stipes and rachises, scales on stipe base look like those on rhizomes, but slightly narrower, $0.4-0.6 \mathrm{~cm}$ long. Lamina 2 to 3-pinnate, abaxial pale green and adaxial shiny pale green when dried, ovate, sometimes pentagonal, $30-52 \times 13-22 \mathrm{~cm}$, papery, base cordate-subtruncate, apex abruptly caudate (sudden decrease at apex) and elongated acute, somewhat with a stalked conform terminal pinna, often 3 pairs of pinnae, alternate, sometimes opposite, distance between the lowest pinnae to the next adjacent pinnae 4 to $6 \mathrm{~cm}$, between 2 alternate pinnae $0.1-1.1 \mathrm{~cm}$; the lowest pinnae elongated at base, larger than the others, obliquely deltoid, $15-20 \times 7-9 \mathrm{~cm}, 0.8$ $1.2 \mathrm{~cm}$ stalk, base broadly rounded, or cordate, apex acuminate, the upper pinnae base cordate, rounded-truncate, apex acuminate, middle pinnae lanceolate, $20 \times 5 \mathrm{~cm}$; Pinnules $8-10$ pairs, $2 \times 0,7 \mathrm{~cm}$, oblong-lanceolate, base aboard cuneate, apex obtuse with margin aristate, lobed 1/3-1/4 toward costae. Sori orbicular, distributed in the middle of veinlet and margin or sub margin, 2-6 pairs divided in 2 rows on the pinnules, reddish brown; indusia orbicularreniform, membranous, entire, persistent attached to veinlet; spore ellipsoidal, 33-40 $\mu \mathrm{m}$, irregularly inflated, sparsely echinulate folds.

Taxonomic notes: 1.- Phylogenetically, this species is nested to a clade containing nine other different accessions named A. simplicior from result of Lu et al. [4] and this species is notorious for the variation in some morphological characters. That why, it is not a surprise that in comparison to Chinese A. simplicior, the Vietnamese specimens more obtuse and oblong 
pinnule apexes; 2.-Arachniodes simplicior is most similar to A. chinensis (Rosenstock 1914: 130) [10] Ching (1962: 257) [11] in having lanceolate scales at stipe bases and long filiform scales on rachis, lamina apex abruptly caudate with a stalked conform terminal pinna, but the new reported species has dark-brown scales, lowest pinnae obliquely deltoid, lamina ovate, papery, whereas A. chinensis has blackish scales, lanceolate-oblong pinnae, lamina narrower, ovate-oblong and thicker.

Nomenclature note: When Makino (1901: 65-66) described Aspidium aristatum var. simplicior, five gatherings (T. Makino s.n., 1884; T. Makino s.n., 1889, Y.Yoshinaga s.n., Z.Umemura s.n., 1896, Z.Umemura s.n., 1895) were cited in the protologue but no holotype was designated. When studying those specimens (syntypes), we designated the sheet MAK012702 as the lectotype.

Distribution and habitats: Korea (Hongdao), China (Guangxi, Guizhou, Yunnan), Japan (Tosa, Iyo, Ise) and Vietnam (Quang Binh). It grows well in warm temperate and tropical areas. In Vietnam, found several individuals in one place only and preferred acidic soils among limestone rocks.

Additional specimens examined: Vietnam: Quang Binh province, Minh Hoa district, Hoa Son commune, Hoa Luong village, $17^{\circ} 466^{\prime} 55.76^{\prime \prime}$ $\mathrm{N} 105^{\circ} 53^{\prime} 0.70^{\prime \prime E}$, a limestone mountain opposite of the forest station at elev. $600 \mathrm{~m}, 15$ November, 2014, Zhang and Lu 7461 (VNMN).

\section{Acknowledgements}

All authors thank the curators of TI, MAK and Atsushi E. (TNS) for providing images of types. We would sincerely acknowledge staffs, curator of the VNMN herbarium of Vietnam National Museum of Nature, VAST for their permissions to work on Arachniodes collections and enabling us to study these specimens here.
This research is funded by the Vietnam National Foundation for Science and Technology Development (NAFOSTED) under grant number 106.03-2019.313.

\section{References}

[1] H. He, A Taxonomic Study of the Fern Genus Arachniodes Blume (Dryopteridaceae) from China, American Fern Journal 94(4) (2004) 163182.

[2] The Pteridophyte Phylogeny Group, A community -derived classification for extant lycophytes and ferns, Journal of Systematics and Evolution 6 (54) (2016) 588.

[3] http://powo.science.kew.org/taxon/urn:lsid:ipni.o rg:names:17023720-1\#source-KB.

[4] T.N. Lu, A. Ebihara, H. He, L. Zhang L, X.-M. Zhou, R. Knapp, P. Kamau, D. Lorence, X.-F. Gao, L.-B. Zhang. A plastid phylogeny of the fern genus Arachniodes (Dryopteridaceae), Molecular Phylogenetics and Evolution 133 (2019) 214-235.

[5] H. He, S.-G. Wu, J.-Y. Xiang, D.S. Barrington. Arachniodes Blume. In: Wu Z.-Y., Raven P.H., Hong D.-Y., (Eds.) Flora of China 2-3 (2013) 542558. http://www.efloras.org/.

[6] P.K. Loc, The updated checklist of the Fern Flora of Vietnam following the classification scheme of A. Smith et al. Journal of Fairylake Botanical Garden 9(3) (2006) 1-13.

[7] P.H. Ho, An illustrated flora of Vietnam, Vol. 1. Young Publishing House Ho Chi Minh City, 1991, 235-236.

[8] P.K. Loc, Checklist plants of Vietnam. Agricultural Publishing House, Hanoi, 2001, Vol I: $1009-1010$.

[9] T.N. Lu, L. Zhang, X.-M. Zhou, X.-F. Gao, L.-B. Zhang 2018. Three new species of the fern genus Arachniodes (Dryopteridaceae) from Vietnam, Phytotaxa 376 (3), 126-132.

[10] E. Rosenstock, XXXV. Filices extremi orientis novae II. Repertorium Specierum Novarum Regni Vegetabilis 13(355-358) (1914) 129-135. https:// doi.org/10.1002/fedr.19140130902.

[11] R.-C. Ching, On the nomenclature of the compound-leaved polysticha. Acta Botanica Sinica 10 (1962) 253-263. 

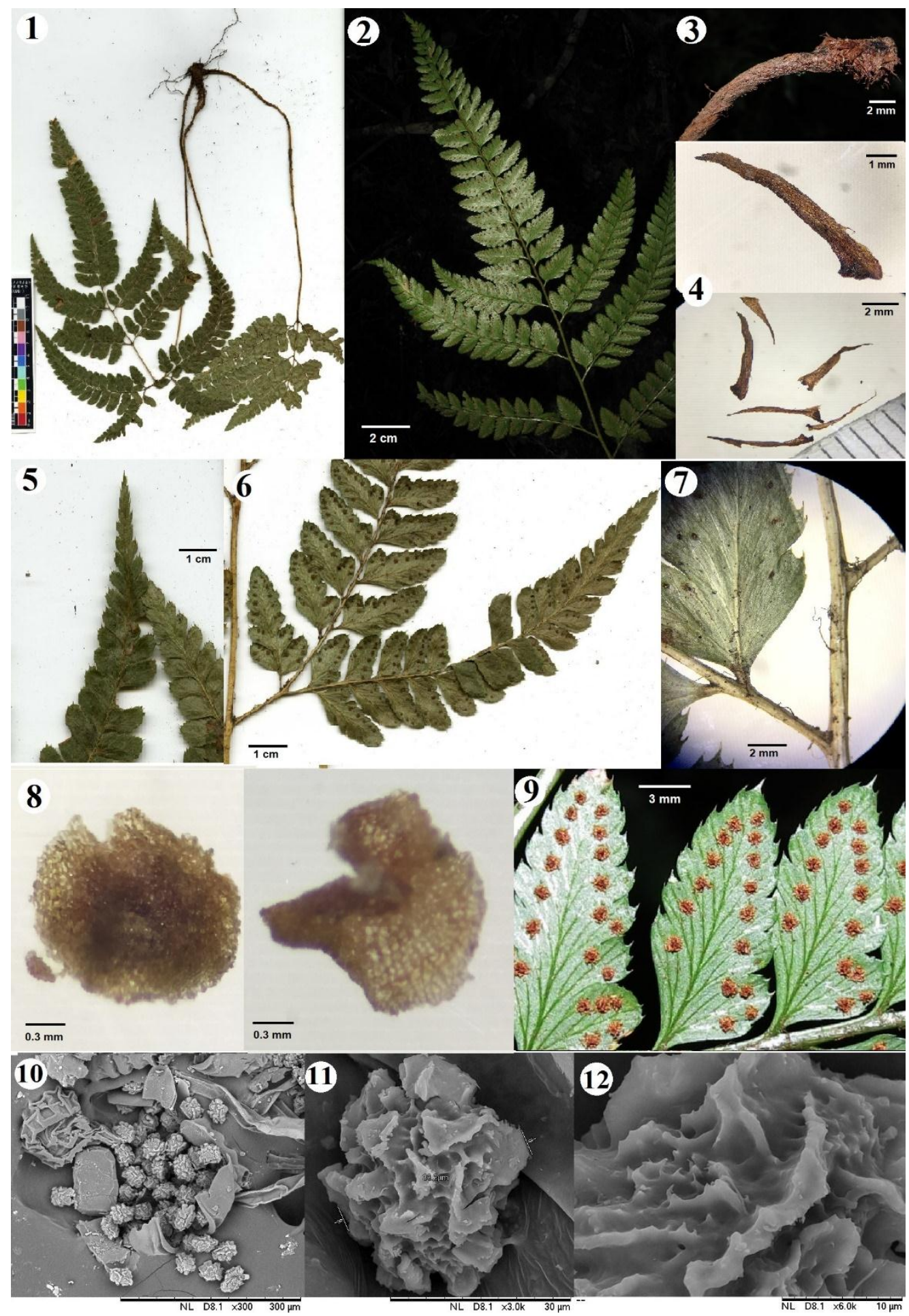

Figure 1. 1. The scan of whole plant. 2. Apex. 3. Base of stipe shows scales. 4. Rhizome and base stipe scales. 5. Part of pinnae. 6. The lowest pinnae. 7. Part of rachis and pinnule. 8. Entire indusia. 9. Pinnules show sori position and margin. 10-12. Spores by Scanning Electron Microscope (SEM). 


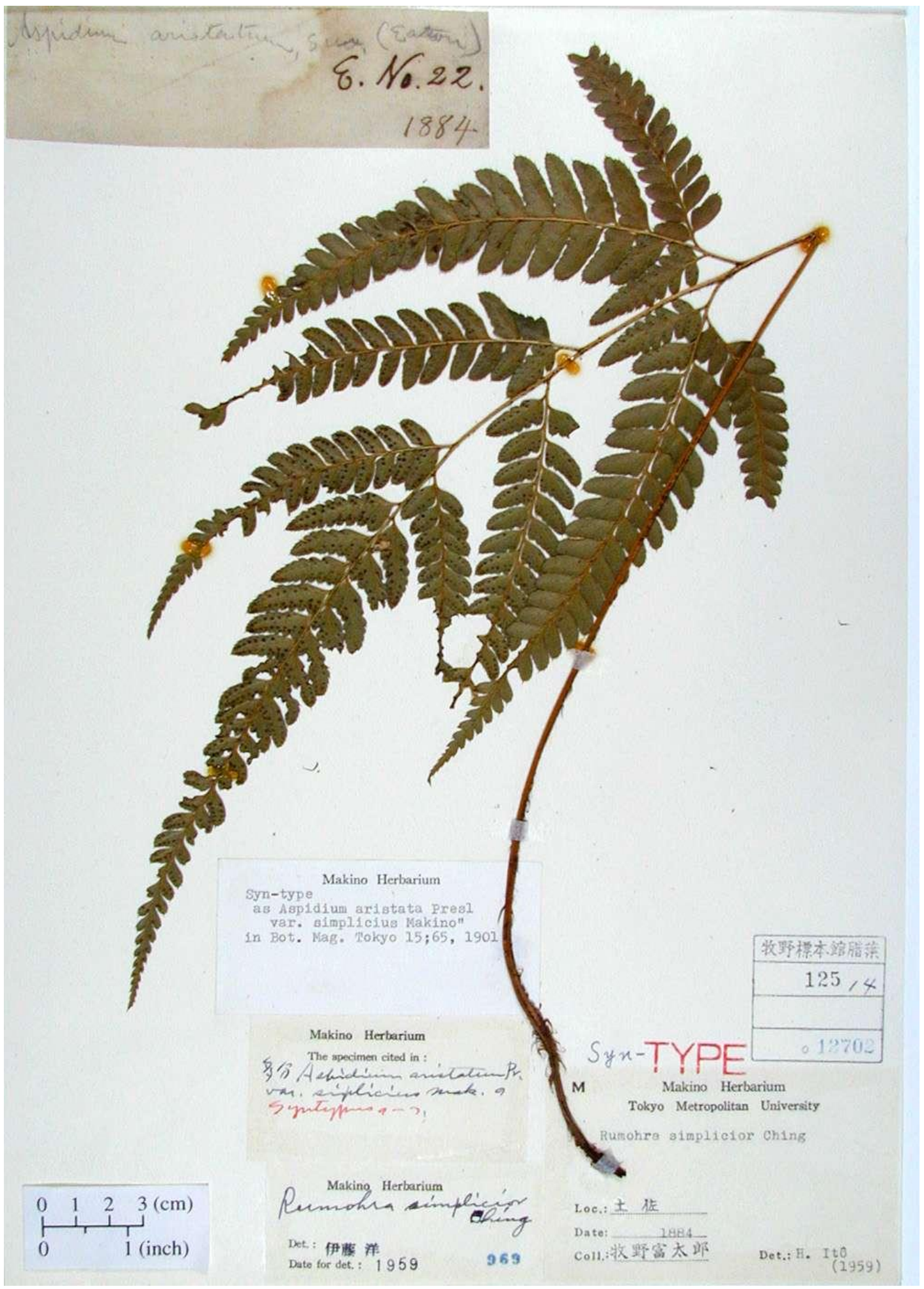

Figure 2. Lectotype of Arachniodes simplicior (Makino) Ohwi.X. 